Georgetown University Law Center

Scholarship @ GEORGETOWN LAW

2003

\title{
Virtue Jurisprudence: A Virtue-Centered Theory of Judging
}

Lawrence B. Solum

Georgetown University Law Center, Ibs32@law.georgetown.edu

This paper can be downloaded free of charge from:

https://scholarship.law.georgetown.edu/facpub/880

http://ssrn.com/abstract=310417

34 Metaphilosophy 178-213 (2003)

This open-access article is brought to you by the Georgetown Law Library. Posted with permission of the author. Follow this and additional works at: https://scholarship.law.georgetown.edu/facpub

Part of the Ethics and Political Philosophy Commons, Judges Commons, Jurisprudence Commons, and the Legal Theory Commons 
Lawrence B. Solum 2003

Published by Blackwell Publishing, 108 Cowley Road, Oxford OX4 1JF, UK and

350 Main Street, Malden, MA 2148, USA

METAPHLOSOPHY

Vol. 34, Nos. 1/2, January 2003

0226-1068

\title{
VIRTUE JURISPRUDENCE A VIRTUE-CENTRED THEORY OF JUDGING
}

\author{
LAWRENCE B. SOLUM
}

\begin{abstract}
Virtue jurisprudence" is a normative and explanatory theory of law that unises the resources of virtue ethics to answer the central questions of legal theory. The main focus of this essay is the development of a virtue-centred theory of judging. The exposition of the theory begins with exploration of defects in judicial character, such as corruption and incompetence. Next, an account of judicial virtue is introduced. This includes judicial wisdom, a form of phronesis, or sound practical judgement. A virtue-centred account of justice is defended against the argument that theories of fairness are prior to theories of justice. The cen rality of virtue as a character cait can be drawn out by analysing the virtue of justice into constuent elements. These include judicial impariality (even-handed sympathy for those affected by adjudication) and judicial integrity (respect for the law and concern for its coherence). The essay argues that a virtue-centred theory accounts for the role that virtuous practical judgement plays in the application of rules to particular fact situations. Moreover, it contends that a virtue-centred theory of judging can best account for the phenomenon of lawful judicial disagreement. Finally, a virtue-centre approach best accounts for the practice of equity, departure from the rules based on the judge's appreciation of the particular characteristics of individual fact situations.
\end{abstract}

Keywords: ethics, justice, jurisprudence, law, virtue

\section{Introduction}

"Virtue jurisprudence" is a nonnative and explanatory theory of law that utilises the resources of virtue epistemology,${ }^{1}$ virtue ethics, ${ }^{2}$ and virtue politics ${ }^{3}$ to answer the central questions of legal theory. ${ }^{4}$ In a sense, virtue

1 See Zagzebski 1996. See also Fairweather and Zagzebski 2001

2 The literature on virtue ethics is now vast. My own work has been especially influenced by the following contemporary works: Foot 1978; 2001; Hursthouse 1999; MacIntyre 1984; and Sherman 1989. See also Crisp and Slote 1997; Statman 1997; and Crisp 1996.

3 See Crisp and Slote 1997, "Introduction."

${ }^{4}$ The phrase virtue jwispredence is coined on the model of "virtue ethics" and "virtue epistemology." Virtue jurisprudence today is in much the same early stage as "virtue politics." See Crisp and Slote 1997, "Introduction."

Lawrence B. Solum 2003 
jurisprudence is a new theory, drawing on the resources provided by recent developments in moral philosophy, but virtue jurisprudence is also a very old theory, rooted in Aristotle's conception of ethics, politics, and the nature of law. ${ }^{5} \mathrm{~A}$ central thesis of virtue jurisprudence is that rival accounts of the nature of law are seriously deficient, because they do not and cannot provide an adequate account of the relationship between law and character. This essay explores one aspect of that thesis in the context of theories of judging.

I shall begin my exposition of virtue jurisprudence by comparing the situation of legal theory today to the condition of ethics a few decades ago when Elizabeth Anscombe (1997) wrote her essay "Modern Moral Philosophy." Then I shall proceed to a very broad-brush sketch of the issues that might be encompassed by virtue jurisprudence. After these introductory topics have been explored, I shall tum to the central part of the paper, an outline of a virtue-centred theory of judging. Finally, I contend that a virtue-centred theory of judging offers an adequate account of the practice of equity, but competing theories of judging run into trouble on this score.

A. Law and Modern Moral Philosophy

In "Modern Moral Philosophy" Elizabeth Anscombe famously noted persistent problems with the deontological and utilitarian approaches that dominated normative ethics when she wrote in 1958. Modern legal theory has strong connections with modern moral philosophy. Historically, the connection is evident in the work of Jeremy Bentham, ${ }^{6}$ combined a conceptual separation of law and morality with a utilitarian program of legal ref orm. ${ }^{7}$ Contemporary legal scholarship frequently invokes general

${ }^{5}$ My understanding of Aristotle's theory of the virtues reflects a variety of sources. See, e.g., Broadie 1991; Hardie 1980; Kraut 1989; 2002. See also Rorty 1980. I am also indebted to Gavin Lawrence for his course on Aristotle's ethics at the University of California at Los Angeles and to Christine Korsgaard for her seminar on Aristotle's ethics at Harvard University.

- See generally Bentham 1988; 1996.

7 The relationship between legal positivism and normative criticism of the law is controversial. Frederick Schauer (1996) has articulated the idea that legal positivism enables moral criticism of the law by making the separation between legality and morality clear. Julie Dickson (2001) criticises this line of argument on the grounds that it involves "wishful thinking." Dickson believes that legal positivism is a theory of what lawis, i.e., a theory that specif ies the necessary and sufficient conditions for a social practice to count as a law. Therefore, she argues, the beneficial consequences of legal positivism cannot count as an argument for the acceptance of legal positivism as a theory of the nature of law. The acceptance of legal positivism must depend on whether it does, in fact, capture the necessary and suf ficient conditions for law; any beneficial consequences would be mere epiphenomena. Discussion of this issue is beyond the scope of this essay, except for one brief observation. Dickson's argument assumes that the concept of "law" designates a social practice, the nature of which is fixed by the necessary and suf ficient conditions that constitute its conceptual structure. If, however, law is a social practice, the nature of which is contestable and subject to revision, then it would follow that legal positivism is indeed a normative position and that Schauer is not guilty of wishful thinking. 
moral theories, including preference-satisfaction utilitarianism ${ }^{8}$ and deontological theories like Kant's,' to make arguments about what the law should be. Such normative legal theories are addressed to lawmakers (in the broad sense), including legislators and adjudicators. Developments in political philosophy, sparked by John Rawls's Theory of Justice ${ }^{\mathbf{1 0}}$ and its libertarian ${ }^{11}$ and communitarian ${ }^{12}$ critics, have met with avid attention from the legal academy.

There is, however, an exception to general reflection of developments in moral philosophy in legal theory. Legal philosophy (as practised by philosophers or academic lawyers) has only recently paid attention to one of the most significant developments in moral theory in the second half of the twentieth century, the emergence of virtue ethics.

An outpouring of articles and monographs attests to the interest of philosophers in virtue ethics. ${ }^{13}$ In the law, the situation has been different. The hegemony of deontological and utilitarian theories prevails, at least among legal theorists working in the common-law tradition..$^{14}$ There are, however, a growing number of exceptions to this hegemony, ${ }^{15}$ including work on antitrust law, ${ }^{16}$ civil rights law, ${ }^{17}$ corporate law, ${ }^{18}$ criminal law, ${ }^{19}$

- Pref erence-satisf action utilitarianism provides the moral foundation for most of normative law and economics. For a general statement, see Kaplow and Shavell 2002.

- See, e.g., Bricker 1999; Haemmerli 1999; Housman 1992; Lillich 1997; Wright 2002. See also Symposium on Kantian Legal Theory 1987.

1- Use of Rawls's theory in general and the original position in various forms has become commonplace in legal scholarship. See, e.g., Jackson 1986 (bankruptcy law); Gordon 1989 (intellectual property law); Schroeder 1986 (tort law). See also Solum 1994b (discussing use of Rawls in legal scholarship and judicial opinions).

${ }^{11}$ The contemporary classic is Nozick 1977. For applications in legal scholarship, see, e.g., Byrne 1995; Carens 1987; Garcia 2000. An influential libertarian theory of law is offered in Barnett 1998; see also Fleming 2000 (discussing Barnett) and Solum 1999 (discussing Barnett).

${ }_{12}$ One prominent communitarian critique is found in Sandel 1988. For discussions by legal academics, see, e.g., Baker 1985; Forbath 2001; Quinn 2000.

${ }_{13}$ See the sources cited supra note.

${ }^{14}$ For a particularly self-conscious choice to discuss deontology and utilitarianism at the expense of virtue ethics, see Strudler and Orts (1999, 381-82 n. 20): "For the purposes of this Article, we identify utilitarianism as the main normative alternative to deontological theory. We do so for two reasons. First, proponents of economic analysis, the dominant approach to insider trading, of ten regard utilitarianism as the moral foundation of economic analysis. ... Second, utilitarianism has historically been perceived as the strongest competitor to deontology. ... Because of considerations of space, we have had to make some editorial choices about moral theories we discuss and to omit discussions of theories other than deontology and utilitarianism. We intend no slight to virtue ethics, moral development theory, social contract theory, or any of the other moral theories we do not discuss."

15 See, e.g., Arau jo 1994; Brosnan 1989; Galston 1994; Garcia 2001; Heyman 1992; Hirschman 1990; 1992.

16 Robertson 2000.

${ }_{17}$ Arau jo 2002, 433-34.

18 Aaronson 1995; Bainbridge 1997; Beck-Dudley 1996; Nesteruk 1996a; 1996 b.

19 See Huigens 1995; 1998; 2000a; 2000b; 2002 and Muller 1993. 
employment law ${ }^{20}$ environmental law ${ }^{21}$ torts, ${ }^{22}$ legal ethics, ${ }^{23}$ military justice, ${ }^{24}$ pedagogy, ${ }^{25}$ and public-interest law. ${ }^{26}$

"Virtue ethics" and "virtue epistemology" are not, of course, monolithic theories, and I cannot attempt to present a fully developed version of either approach on this occasion. I shall assume (but not argue for) the proposition that Aristotle's ethics counts as an example of virtue ethics. ${ }^{27} \mathrm{In}$ so far as it is possible, I shall attempt to avoid the various controversies surrounding the different varieties of virtue ethics and virtue epistemology. I shall certainly not be able to offer a defence of either theory against its critics.

\section{B. Virtue Jurisprudence}

A full account of the implications of virtue ethics and epistemology for legal theory is a very large topic. Among the issues raised by virtue jurisprudence are the following:

- Virtue ethics has implications for an account of the proper ends of legislation. If the aim of law is to make citizens virtuous (as opposed to maximizing utility or realising a set of moral rights), what are the implications for the content of the laws?

- Virtue ethics has implications for legal ethics. Current approaches to ethical lawyering emphasise deontological moral theory, that is, duties to clients and respect for client autonomy, and these deontological approaches are reflected in the various codes of professional conduct that have been devised for lawyers, judges, and legislators. How can we reconceive legal ethics from a virtue-centred perspective? ${ }^{29}$

- Accounts of the virtue of justice (in particular, Aristotle's and Aquinas's theories of natural justice) have implications for debates between natural lawyers and legal positivists over the nature of law..$^{30}$

2• Sulentic 2001

${ }_{21}$ Gaba 1999a; 1999b and Harsch 1999

${ }^{22}$ Feldman 2000; see Simons 2001

${ }^{23}$ Arau jo 1997; Cochran 1996; 1998; 2000; Feldman 1996; 1999; Perkins 1998; Shaffer

1993; Smith and Montross 1999; Tremblay 1999b.

${ }^{24}$ Hudson 1999; Osiel 1998.

${ }^{25}$ Aaronson 1998; Hirshman 1993.

26 Tremblay 1999 a.

${ }^{27}$ Whether Aristotle had a virtue ethics in the contemporary sense is controversial; I shall not enter into that debate. The position that I attribute to Aristotle serves my purpose even if it turns out to be a neo-Aristotelian variation that is in some way inconsistent with Aristotle's own theory.

23 For discussion of the relationship between lawfulness and virtue in Aristotle, see Kraut 2002. For a contemporary approach that emphasises the cultivation of virtue as the end of law, see George 1995.

${ }^{29}$ For an account that emphasises virtue and especially phronesis but is not rooted in contemporary virtue ethics, see Kronman 1993. For accounts that more directly connect legal ethics and virtue ethics, see sources cited supra note 23.

30 The relationship between Aristotle's account of justice and debates over the nature of law is notoriously obscure. For a reading of Aristotle that is highly suggestive, see the 
On this occasion, however, I shall limit my attention to the implications of a virtue-centred approach for a nonnative therry of judging. Such theories answer the question: How should judges decide the controversies that are presented to them? A virtue-centred theory of judging provides an answer along the following lines: Judges should decide cases in accord with the virtues, or judges should render the decisions that would be made by a virtuous judge.

By way of clarification, I am not making any claim that theories of law should be judge centred. ${ }^{31}$ Nor am I making any claim about the relative merits of judicial lawmaking and legislation. ${ }^{32}$ Those are important topics, ones with which a virtue jurisprudence must grapple. A virtue-centred theory of judging is simply a place to start. ${ }^{33}$

C. What Is a Virtue-Centred Theory of Judging?

Beyond a Thin Theory of Judicial Virtue

There is a sense in which the notion of judicial virtue is likely to prove uncontroversial. For any given normative theory of judging, there is a corresponding account of the qualities that make for a good judge. If we are not too picky about the sort of qualities that we are willing to call "virtues" or "excellences," then we can offer accounts of judicial virtues that correspond to various theories of judging.

Ronald Dworkin's theory of law as integrity provides an example of a theory of judging. ${ }^{34}$ Roughly, we might say that Dworkin believes that judges should decide cases in accord with the nomative theory of law that best fits and justifies the law as a whole. For judges to be able to do this reliably, they will need to possess certain characteristics that we might call judicial virtues - the excellences appropriate to the role of judge. On Dworkin's theory, for example, the intellectual virtue of theoretical wisdom is clearly a prerequisite for excellence in judging. Dworkin's imaginary judge, Hercules, decides cases by constructing the theory that fits and justifies the law as a whole; this task can only be accomplished by someone who is able to appreciate legal complexity and to see the subtle

illuminating and important discussion of book 5 of the Nicomachean Ethics in Kraut 2002, 98-177.

${ }^{31}$ Although my discussion is of theories of judging, I do not mean to imply that virtue jurisprudence should focus only on the virtues of judges. A complete virtue jurisprudence would of fer accounts of the virtues of legislators, executives, citizens, and other legal actors in addition to a theory of judging. Judging, however, is an important case, at least in part because theories of judging are prominent in contemporary jurisprudence.

32 See generally Waldron 1999

${ }^{33}$ Other recent uses of Aristotelian resources in the development of a theory of judging can be found in Modak-Truran 2000 and Henry 1999. My own prior work on a virtuecentred theory of judging includes Solum 1988; 1990; 1994a

${ }^{34}$ See Dworkin 1978; see also Dworkin 1986. 
interconnections between various legal doctrines summarised in the slogan "the law is a seamless web." ${ }^{35}$

Different normative theories of law may result in different lists of the excellences that are appropriate to judging. If it were the case that some qualities of judicial character are necessary for reliably good judging given any plausible normative theory of judicial decision, then an account of these qualities would be what I shall call a "thin" theory of judicial virtue. We might analogise such a thin theory to Rawls's notion of primary goods, ${ }^{36}$ which are sometimes (albeit erroneously) understood as allpurpose means for the realisation of one's conception of the good life. In this picture, the judicial virtues are simply those qualities of character that are required to realise one's conception of goed judging. Thus, a thin theory of judicial virtues might include the intell ectual virtue of theoretical wisdom, which plausibly is necessary for judges to understand complex legal material. Likewise, irrespective of one's particular theory of good judging, it might tum out that certain vices are inconsistent with reliably good judging. Judges who are civic cowards, slavishly seeking approval from others, may be incapable of reliably adhering to any coherent and plausible theory of good judicial decision making. A similar claim might be made about judges who are intemperate or avaricious and thus prone to sharp dealing or susceptible to bribery. Hence, civic courage and temperance might be considered thin judicial virtues.

How a Virtue-Centred Theory Is Distinctive

This essay focuses on a virtue-centred theory of judging as a component of virtue jurisprudence. The aim is to provide arguments that make a virtuecentred theory plausible, but in order to accomplish this task, we need criteria that distinguish a virtue-centred theory of judging from a theory of judicial character that could be incorporated as a module within rival theories of judging. What makes a virtue-centred theory distinctive?

I shall approach this question by explicating the differences between a virtue-centred theory of judging and a thin theory of judicial virtue. A virtue-centred theory of judging differs from a thin theory of judicial virtue in two respects. First, a virtue-centred theory is not limited to those qualities of judicial character that would count as means to good decisions for any plausible theory of what counts as a good decision. Thus, the account that I offer might be characterised as a "thick" rather than a "thin" theory of judicial virtue. But thickness is not sufficient to make a theory virtue centred. For example, it might be that law as integrity can incorporate a

\footnotetext{
${ }^{35}$ Maitland $(1898,13)$ : "Such is the unity of all history that any one who endeavours to tell a piece of it must feel that his first sentence tears a seamless web"; see also Transworld Airlines v. American Coup Exchange $(1990,685)$ (discussing "law's of t-proclaimed seamless web"); Kleinwort Benson Lid. Appellant v. Lincoln City Council Same Respondent 1999 (opinion of Lord Goff of Chieveley).

36 See Rawls 1999, §60, 347-50.
} 
thick theory of judicial virtues. Hercules may need the virtue of judicial integrity, that is, a special concern for the coherence of the law. This virtue might not be important to an act-utilitarian theory of judging. ${ }^{37}$

Second, a thin theory of judicial virtue cannot be focused on judicial character as opposed to judicial decision. Many normative theories of judging are decision (or outcome) centred. A decision-centred theory offers criteria for what should count as a good, right, just, or legally valid decision. For a decision-centred theory of virtue, the notion of a correct decision is primary, and the judicial virtues are derived from it. Thus, Dworkin's description of Hercules begins with the criteria for good decisions and then constructs the ideal judge who is able to render such decisions. A virtue-centred theory does not proceed in this way. I shall begin with an account of a virtuous judge as primary and then proceed to derive the notion of a virtuous decision.

By way of clarification, consider some of the claims that a virtuecentred theory of judging does not need to make. For a theory to be virtue centred, it need not make the claim that judging can be explained solely and exclusively by reference to the virtues. Thus, the full story about correct or just or virtuous decision making will necessarily make reference to facts about the world (including the facts of the disputes that judges decide) and legal facts (including facts about what statutes have been validly enacted, what prior decisions are binding precedent, and so forth). A virtue-centred theory must claim that judicial virtues are a necessary part of the best theory of judging and that judicial virtue plays a central explanatory and normative role. A theory does not lose its status as virtue centred simply because it does not limit its explanatory resources to the virtues alone. ${ }^{38}$

The Aims of the Project

I shall conclude these introductory remarks with a comment about the aims of my project in this essay. The development of a virtue-centred theory of judging may allow us to make progress on two fronts. First, it may contribute to our understanding of normative and explanatory jurisprudence; in particular, a virtue-centred theory of judging organises our views about how judges do and should go about their business. This is my primary aim, and it is the explicit focus of this essay.

${ }^{37}$ I lo not mean to claim that an act utilitarian could not make a case for judicial integrity. My claim is simply that one could plausibly argue that concern for coherence need not be a virtue for a theory that makes the consequences of judicial decisions the measure of their correctness. A rule-utilitarian theory of judging, on the other hand, might need the virtue of judicial integrity.

38 Indeed, it is difficult to imagine how a theory could explain judging without reference to concepts other than virtues. Facts about the world and the law are obviously necessary to describe the cases that judges decide. The question is not whether we admit such facts into our virtue-centred theory. Rather, the question is how such facts relate to the judicial virtues. 
There is a second aim, however. The development of virtue jurisprudence may provide a perspicuous context for testing theories of virtue ethics or virtue epistemology. For example, if virtue ethics offers a genuine altemative to rival moral theories (deontology and consequentialism), then it ought to be able to handle the special case of judging adequately. If virtue ethics can provide an account of judging that does a better job of fitting our considered judgements than do the theories of judging offered by deontological or consequentialist moral theories, then we have a reason that counts in favour of virtue ethics and against these rivals.

With respect to this second aim, there is a sense in which virtue jurisprudence addresses a challenge that it is especially important for virtue ethics to answer adequately. Crudely, we might say that virtue ethics is especially well suited to handling those features of ethical life that are not well served by moral rules. Virtue ethics thrives on the observation that there is no master decision procedure for ethics. ${ }^{39}$ Where virtue ethics seems more awkward is in the cases where adherence to rules and decision procedures has great intuitive plausibility. Judging seems to be the paradigm case in which we want adherence to constraining rules and transparent decision procedures. If virtue ethics can be extended to handle the case of judging, it will have succeeded where many would expect it to fail.

\section{A Sketch of a Virtue-Centred Theory of Judging}

At this point, I shall sketch a virtue-centred theory of judging. The enterprise in this section is to develop an account of good judicial character. This task will be accomplished in four steps. The first step is a brief survey of the ways in which judges can be systematically defective: What are the characteristic defects of judicial character? The second step is an account of the kind of judicial character that will avoid these defects: What makes for a reliably excellent judge? The third step is an exploration of the virtue of justice: What qualities of mind and character make a judge just? The fourth and final step is to state a theory of good judging as a function of good judicial character: What is the relationship between correct judicial decision and good judicial character? We can restate the four questions in the language of the virtues:

- What are the judicial vices?

- What are the judicial virtues?

- What is the virtue of justice?

- What is the structure of a virtue-centred theory of judging?

Each topic will be considered in order.

39 Cf. Rawls 1951.

Lawrence B. Solum 2003 


\section{A. What Are the Judicial Vices?}

I turn initially to the judicial vices. Although there is considerably controversy about what constitutes a good judicial decision, there is considerable agreement about some of the characteristics that mark truly bad judges. Let us begin with these easy cases and work from them to an account of the judicial virtues.

\section{Corruption}

The first (perhaps the worst) judicial vice is avarice or corruption. We know from experience that comuption is a real danger for judges. Judicial avarice expresses itself in the blatant and obvious fonn of soliciting or accepting bribes, and in more subtle financial conflicts of interest, such trading on advance knowledge of the outcome of judicial proceedings or setting a precedent that will benefit a company in which one owns stock. ${ }^{40}$ Corruption is not, of course, a uniquely judicial vice, but judicial corruption is particularly bad, because judges occupy a position of trust and because judicial comuption will often lead to grave injustice to innocent third parties unable to protect themselves. That is, an avaricious decision may lead to a def endant or litigant being denied that to which she is due under the law. Corruption is an especially heinous fault in judicial character, because we expect judges to display exemplary respect for the law. A comupt or avaricious judge cares too much for material rewards or the pleasures they afford and accepts the wrong rewards from the wrong people for the wrong reasons.

Notice, however, that our objection to judicial avarice is not reducible to our concern that litigants get their due. Many judicial decisions are discretionary. Putting aside the controversial question whether "hard cases" in Dworkin's sense involve discretion, there are many issues (for example, the number of witnesses that are permitted to testify on a particular issue) where the decision of a trial-court judge is not significantly constrained by any rule. A comupt decision on such an issue is evil, even if it does not deny any party something to which she is entitled. Indeed, a comupt decision is wrong, even if it does, in fact, give the parties that to which they are entitled as a matter of law. A judge is not better for accepting bribes to render the correct decision.

\section{Civic Cowardice}

A second vice is judicial cowardice. I do not mean a disposition to excessive fear of solely or primarily physical danger. Judges in the United States and the United Kingdom rarely make official decisions that expose them to significant risk of harm. Such risk may be more common in other legal cultures; for example, narco-terrorist retaliation against judges in

\footnotetext{
${ }^{4}$ For general background on judicial corruption and efforts to control it, see National Commission on Judicial Discipline and Removal 1993; Simon 1994.
}

- Lawrence B. Solum 2003 
Colombia is common. Even in relatively stable societies it is not unusual to leam of a death threat against a judge. More frequently, however, judges may fear the loss of office or the loss of the opportunity to gain promotions. The election of judges is common in state judicial systems in the United States, for example. In some legal systems, judges eam promotions from lower courts to higher courts through a civil-service system. Even in a system with life tenure (such as the federal system in the United States) opportunities for promotion to a higher court or other position of prestige may depend on avoiding unpopular decisions on matters of public interest. More simply, judges may fear the opinions of the public and the powerful as well as the consequences of such opinions for their social positions. Judges with the vice of civic cowardice fear too much for their careers and social prestige, and hence are swayed by concern for their reputation on the wrong occasions and for the wrong reasons.

Cowardly decisions are bad ones for reasons that are much the same as those advanced for the conclusion that comupt decisions are evil. Judges who rule against unpopular criminal defendants because they fear they will not be re-elected are likely to render decisions that are unjust because they deny to defendants that to which they are due. Moreover, a cowardly decision is properly criticised even if the outcome of the decision is within a judge's range of discretion or is, in fact, legally correct. Good judging requires that the right decision be reached for the right reason.

\section{Bad Temper}

A third judicial vice is bad temper. Trials in particular and the processes of civil and criminal justice in general are emotionally charged. Criminal defendants, litigants, and lawyers are all likely to disagree with, criticise, and even disrespect judicial officers. Judges who are quick to anger or who harbour resentments that occasionally burst into inappropriate explosions are likely to damage the judicial process. Their anger may cloud their judgement, leading them to render decisions that are wrong or to exercise their discretion in a biased manner. Even when inappropriate anger does not directly affect the outcome of judicial proceedings, it may undennine the confidence of the participants and public in the judge's fairness, and hence impair the effectiveness of the judicial process as a mechanism for resolving conflicts in a manner that gains acceptance and support from those affected.

\section{Incompetence}

The three judicial vices that I have considered so far (avarice, cowardice, and bad temper) involve defects in judges' affective states, their emotions or desires. What of defects in their intellectual equipment? Sometimes the law is subtle or complex, and a judge may go wrong by failing to grasp the law. When judges fail to understand the law, their decisions are likely to be unjust. The judge who fails to comprehend a complex rule or subtle 
distinction lacks the equipment to reliably hit the target, a legally correct result. Of course, even a blindfolded archer may hit the target, and even an incompetent judge may stumble on a legally correct result. If the decision is the kind that requires justification in the form of a written opinion, however, even a lucky guess about the outcome will not save a judge who lacks the ability to grasp the law intellectually. A well-reasoned opinion on a complex issue of law cannot be the product of good luck. In a system that incorporates the rule of stare decisis, a badly written opinion can result in injustice in the decision of many other cases, even if the outcome in the case in which the opinion was rendered was correct.

Although lawyers are well familiar with the problem of intellectually deficient judges, our public vocabulary is not rich with respect to this vice. We might say that the intellectually deficient judge suffers from judicial incompetence, or we might employ a less direct locution, saying such judges are "less than brilliant," "somewhat dense," or, more pejoratively, "stupid."

\section{Foolishness}

If one intellectual failure is related to legal complexity or subtlety, there is another sort of intellectual failure, associated with a lack of sound judgement. A judge can be foolish because the judge lacks the ability to distinguish between what is workable and what is impracticable. A related failure is the inability to distinguish between the aspects of a dispute that are important and those that are trivial. A judge who is a poor judge of character will be unable to tell honest witnesses from liars or to discern the difference between zealous advocacy and sharp dealing. Even judges who have a strong theoretical grasp of the law may go badly wrong if they lack common sense and sound practical judgement.

Failures in practical judgement by judges can have serious consequences. Judicial responsibility extends beyond the task of simply getting the law right and then applying it to the undisputed facts. Perhaps the clearest example of the dangers of bad judgement is the complex injunction. When a judge is required to supervise a complex institution, such as a penal system or a school district, the consequences of bad judgement can be serious indeed. Getting the law right may help the judge to see the legal goal that ongoing supervision of a complex injunction requires, but this is not sufficient. An impractical mandate or a poor allocation of resources can have devastating consequences, even without a mistake of law.

Let us pause and examine our brief and incomplete list of judicial vices. Judges who are avaricious, cowardly, bad tempered, stupid, or impractical are likely to go systematically wrong in their decisions. What are the qualities of character that avoid these defects? What qualities of character dispose a judge to make excellent decisions? In other words, what are the judicial virtues? 


\section{B. What Are the Judicial Virtues?}

Our investigation of the judicial vices suggests that judicial virtue has much in common with human excellence in general. The intellectual virtues of theoretical and practical wisdom and the moral virtues of courage, temperance, and good temper are required for excellence in judging, just as they are required for any flourishing human life. To put it the same point negatively, a vicious person - someone who is foolish, lacks common sense, is avaricious, cowardly, and prone to disproportionate anger - lacks the equipment for excellence in any social endeavour, ${ }^{41}$ including a career as a judge.

Assuming that judicial excellence requires the possession of the virtues to at least some degree, the next step is to give an account of the virtues as they operate in the context of judging. I shall briefly describe five aspects of judicial virtue: (1) judicial temperance, (2) judicial courage, (3) judicial temperament, (4) judicial intelligence, and (5) judicial wisdom. I shall also discuss the virtue of justice, but that discussion will be postponed because of the special problems posed by justice. ${ }^{42}$

Before proceeding, two qualifications are in order. First, by calling these qualities "judicial virtues" I do not mean to imply any strong claim about their underlying nature. The psychology of the judicial virtues may well be the same as the virtues in general. The distinctive features of the judicial virtues may be attributable to the contexts in which they are exercised. ${ }^{43}$ Because judges assume a special role and face situations that are distinct from the circumstances faced by the rest of us, the virtues they exercise can be described in a distinctive way. Second, the list of judicial virtues offered here is intended to be illustrative, not exhaustive. ${ }^{44}$ Good judging requires more than just these five qualities of character.

Judicial Temperance

Consider first the virtue of temperance. Good judging requires that one's desires be in order. This is clear when the temperate judge is contrasted to the judge who lacks the ability to control her appetites. Judges who care too much for their own pleasures are prone to temptation; they are likely

\footnotetext{
${ }^{41}$ It is not clear to me that virtue is require for excellence in all human endeavours. It may, for example, be possible to be a great painter or singer, despite a vicious character. The claim that I make in the text is that virtue is required for human endeavours that are social and practical in nature, although I of fer no def ence for that claim on this occasion.

${ }^{42}$ For other discussions of judicial virtues, see Araujo 1994; see also Glendon 1994; Luban 1992, 242-56; Pinkard 1992, 281-82.

${ }^{43}$ The use of "may" indicates that I do not take a stand here. I am not ruling out the possibility that good judges develop emotional responses that are psychologically different from those who do not occupy this (or a relevantly similar) social role.

${ }^{44}$ A number of readers have suggested judicial virtues that might be added to my list. For example, judges in common-law systems are sometimes required to write opinions that justify their decisions. In order to to this well, judges need certain skills and capacities that might be called virtues - eloquence and wit come to mind.
} 
to be swayed from the course of reason and justice by the temptations of pleasure. A libertine judge may indulge in pleasures that interfere with the heavy deliberative demands of the office. Hence, the saying "sober as a judge" reflects the popular understanding that excessive indulgence in hedonist pleasures would interfere with excellence in the judicial role.

As in the case of temperance generally, it is a bit difficult to see the virtue of judicial temperance as a mean between two opposing vices. Asceticism may interfere with a flourishing human life, but it is not so clear that it interferes in any distinctive way with the demands that we place on judges. Perhaps extreme judicial asceticism would interfere with the judge's ability to sympathise and understand motivations and desires of lawyers, parties, and witnesses. If asceticism were a judicial vice, the explanation would lie in the connection of this quality to a lack of sound practical judgement.

Judicial Courage

A second virtue, judicial courage, corresponds to the vice of civic cowardice. The ordinary moral virtue of courage is sometimes thought to serve as a relatively clear example of Aristotle's doctrine of the mean. ${ }^{45}$ Courage is a mean with respect to the morally neutral emotion of fear. The disposition to inordinate fear is cowardice. The opposing vice, rashness, is the disposition to insufficient fear. The coward is easily intimidated and does not take worthwhile risks. The rash person fails to perceive genuine danger and so is prone to injury from foolhardy risk taking.

Judicial courage is a fonn of "civic courage," distinguishing this quality of character from courage with respect to physical danger. The courageous judge is willing to risk career and reputation for the ends of justice. In the case of judging, it is a bit difficult to see the virtue as a mean between two opposing vices. If civic cowardice, too much fear of risk, is a familiar judicial vice, it is a bit difficult to imagine the judge who cares too little for his career and reputation. In special circumstances, we can imagine a judge who is too willing to throw away reputation and influence on a case that is not worthy of the sacrifice. But this case will need to be a special one, because in ordinary circumstances we believe that judges should do as the law and justice require in every case, not just important. Even the small injuries of little people should be important to judges. ${ }^{46}$ Perhaps in a defective society, where one's ability to prevent grave injustice depends on one's willingness to inflict minor injustice, we might say that judges should be neither too fearful nor too careless of the risks of unpopular decisions. Such a society is defective, however, simply because it puts judges in just such a position.

${ }^{45}$ For doubts about this, see Pears 1980

46 As Learned Hand put it, "It is the daily; it is the small; it is the cumulative in juries of little people that we are here to protect ... if we are to keep our democracy, there must be one commandment: thou shalt not ration justice." See Baldwin 1997, 58. 
This is not to say that a judge should not care about her reputation or public opinion. A judge whose public reputation is good may be enabled to do good judicial work. Civic rashness is indeed a vice. It is a mistake for judges to sacrifice their reputations on the wrong occasions, for the wrong reasons, or by doing the wrong things. A judge may engage in extrajudicial behaviour that brings shame or ridicule. But the defect here is not likely to be too little fear of civic disrepute for unpopular decisions. Rather, some other defect is likely to be involved. Bad temper, immoderation, poor judgement may all result in a poor reputation or damage one's opportunities for civic rewards, but all these vices should also be avoided in themselves and not simply because they reflect a lack of civic courage.

Judicial Temperament

A third virtue, judicial temperament, corresponds to the vice of bad temper. The traditional concern in judicial selection with judicial temperament is illuminated by Aristotle's account of the virtue of good temper, or proates: the disposition to anger that is proportionate to the provocation and the situation ${ }^{47}$ Good temper is a mean between excessive and deficient dispositions to anger. The vice of excess was illustrated circa 1968 and 1969 in the United States by Judge Hoffman's disproportionate rage in the Chicago Seven trial: his extreme anger produced a spectacle that undermined public confidence in the orderly administration of justice. But being too slow to anger is also a judicial vice. A judge who fails to respond with appropriate outrage in the face of misconduct can have a similar, if less dramatic, effect: a courtroom that is out of control is almost as bad as one in which defendants are bound and gagged. The virtue of good temper requires that judges feel outrage on the right occasions for the right reasons and that they demonstrate their anger in an appropriate manner.

Judicial Intelligence

The corrective for the vices of judicial stupidity and ignorance is a fonn of sophia, or theoretical wisdom. I shall use the phrase judicial intelligence to refer to excellence in understanding and theorising about the law. A good judge must be leamed in the law; she must have the ability to engage in sophisticated legal reasoning. ${ }^{48}$ Moreover, judges need the ability to grasp the facts of disputes that may involve particular disciplines such as accounting, finance, engineering, or chemistry. Of course, judicial intelligence is

${ }^{47}$ Aristotle 1976, 1125b27-31.

42 Judges must be learned in the law in two senses. First, they must be learned in the sense that they actually know a great deal about the law that is relevant to their jurisdiction. Second, they must be learned in the sense that they have the cognitive capacities, experience, and skills that enable the acquisition of legal knowledge. Being learned in the first sense is not an intellectual virtue, but being learne in the second sense is. Being learned in the first sense is, however, likely to be a precondition for the development of being learned in the second sense.

Lawrence B. Solum 2003 
related to theoretical wisdom in general, but the two are not necessarily identical. The talents that produce theoretical wisdom in the law may be different from those that produce the analogous intellectual virtue in physics, philosophy, or microbiology. Or it may be that theoretical wisdom is the same for all these disciplines. If this is the case, then judicial intelligence may simply be general theoretical wisdom supplemented by the skills or knacks that produce fine legal thought combined with deep knowledge of the law.

Judicial Wisdom

The final virtue on my short list is the corrective for bad judgement or foolishness. I shall use the phrase judicial wisdom to refer to a judge's possession of the virtue of phronesis, or practical wisdom: the good judge must possess practical wisdom in her selection of the proper legal ends and means. ${ }^{49}$ Practical wisdom is the virtue that enables one to make good choices in particular circumstances. The person of practical wisdom knows which particular ends are worth pursuing and which means are best suited to achieve those ends. Judicial wisdom is simply the virtue of practical wisdom as applied to the choices that must be made by judges. The practically wise judge has developed excellence in knowing what goals to pursue in the particular case and excellence in choosing the means to accomplish those goals. In the literature of legal theory, Karl Llewellyn's notion of "situation sense" captures much of the content of the notion that judicial wisdom corresponds to the intellectual virtue of phronesis. ${ }^{50}$

This abstract account of judicial wisdom can be made more concrete by considering the contrast between practical wisdom and theoretical wisdom in the judicial context. The judge who possesses theoretical wisdom is the master of legal theory, with the ability to engage in sophisticated legal reasoning and insight into subtle connections in legal doctrine. But even a judge who possesses judicial intelligence is not necessarily a reliably good judge, even if she employs the correct decision procedure in her judicial decision making. Why not? An answer to this question begins by clarifying the distinction between judicial intelligence and judicial wisdom.

As an illustration of the distinction between theoretical and practical wisdom, consider the United States Supreme Court's articulation of a constitutional rule governing the free speech of lawyers in Gentile v. State Bar of Nevada (1991). ${ }^{51}$ Gentile was disciplined by the Nevada Bar for holding a press conference in which he charged that a witness against his client had really committed the offence. Although the Court reversed the

\footnotetext{
49 My account of phronesis has been influenced by many sources. See, e.g., MacIntyre 1984; Hardie 1980, 212-39; Engberg-Pedersen 1983. For a discussion of phronesis and the legal craft, see Scharffs 2001.

5• Llewellyn 1960 59-61, 121-57, 206-08; Twining 1973 216-27; see also Farber 1991 (contemporary application of Llewellyn's idea).

${ }^{51}$ See Solum 1991, 16.
}

- Lawrence B. Solum 2003 
conviction on other grounds, Chief Justice Rehnquist's opimion for a majority of the Court held that the "substantial likelihood of material prejudice" standard used in the Model Rules of Professional Conduct does not violate a lawyer's right to freedom of speech; Rehnquist rejected the argument that some version of the "clear and present danger" standard was constitutionally required.

Whatever the merits of the theoretical debate in Gentile over the proper first-amendment standard, it misses an essential practical point expressed by former California Supreme Court Justice Otto Kaus in Younger v. Smith (1973), a case involving an issue very similar to the one raised in Gentile..$^{52}$ As Justice Kaus wryly put it,

[P]endantic appellate debates over the correct criterion are good clean fun for those who enjoy that sort of thing, but of precious little help to a trial judge who must silence the sources of prejudicial pre-rial publicity as soon as possible, or risk spending weeks or months wing a case which is doomed to be reversed, should it result in a conviction. (Younger v. Smith 1973, 160)

Requiring a trial judge to find that a lawyer's conduct creates some quantum of risk "is simply to require him to palm off guesswork as finding" $(1973,164)$, said Justice Kaus. For our purposes, the point of Kaus's opinion was this: theoretical sophistication is no substitute for practical judgement. The abstract standard that best fits the contours of the freedom of speech doctrine can be a practical disaster if it is based on false assumptions about what trial judges can do.

Otto Kaus was one of many common-law judges whose careers exemplify the virtue of practical wisdom or, as I call it, judicial wisdom. As the eminent appellate lawyer Ellis Horvitz said of Kaus, "To an extraordinary degree, he possessed all of the important judicial virtues." ${ }^{53}$ Kaus's opinion in Younger illustrates the relevance of the virtue of judicial wisdom at the appellate level. The need for common sense at the trial level is relatively obvious: trial judges need managerial skills that are not supplied by legal theory. ${ }^{54}$ But the virtue of practical wisdom is a prerequisite for excellence in appellate judging as well. ${ }^{55}$ The practically wise judge has an intuitive

${ }^{52}$ Younger was decided while Justice Kaus was on the bench of the Calif ornia Court of Appeal.

${ }_{53}$ See Horvitz 1997

${ }^{54}$ See Resnick 1982

${ }^{55}$ In oral comments on prior work, Kent Greenawalt and Barbara Herman have suggested that the virtues of trial and appellate judges may be importantly different from the virtues of trial-court judges. See also Herman 1988, 1663-64: "If social role def ines judicial virtue, one might well ask whether there is enough unity in the role across courts to provide useful content to the term good judge. If there are radical differences, then there is room to question the transitivity of virtue from lower to higher courts. An exhaustive list of virtues obscures rather than answers the question." As the text suggests, I do not believe that the differences are fundamental, but a full discussion of that question is beyond my task in this essay.

Lawrence B. Solum 2003 
sense as to how real-life lawyers and parties will react to judicial decisions. Judicial wisdom is required in order to know whether a particular doctrinal formulation will work in practice. ${ }^{56}$

\section{What is the Virtue of Justice?}

I have left one virtue off the list, and it is the virtue that seems crucial in the case of judges. This is the virtue of justice. We are not tempted to name the distinctively judicial form of this virtue "judicial justice," as we could so name judicial courage, judicial wisdom, or judicial temperament. This is not because there is no association but rather because the association is too close. We call high judges "justices," we call the buildings they occupy the "halls of justice," and we call what they do "the administration of justice." If we know anything about judges, it is that they ought to be just. If judges should possess any virtue, then surely they should possess the virtue of justice.

\section{The Centrality of Justice}

If justice is a judicial virtue, how does it relate to the others? It seems clear that the virtue of justice is central. We can imagine a judge who has the natural virtues of temperance, courage, and good temper. Suppose this judge has the right intellectual equipment as well, a strong intellect, a good sense of practicality, and situation sense in matters legal. But if such a judge lacked the virtue of justice, then all the rest would be for naught. Put aside the question of whether one could lack justice but possess all the other judicial virtues (as natural virtues). ${ }^{57}$ If, for the sake of argument, we can imagine the unjust man who is fully endowed with intellect and the natural virtues but lacking in justice, it is clear that such an adjudicator would be an especially bad judge..$^{58}$ Taking the problem from the other end, if there could be a judge who lacked the natural virtues but possessed a strongly developed virtue of justice, we might have a good judge who was not a very good human. Off the bench, the life of the just (but otherwise vicious) judge might be a disaster, but we would seem to lack grounds for criticism if all of the judge's decisions were just.

Laying this thought experiment aside, our working hypothesis is that justice is an essential virtue for excellence in judging. Without justice, judging carmot be good. With justice, judging must be good. Justice, we might say, is the cardinal virtue of judging.

56 There is a great deal more to say about the need for practical wisdom at the appellate level. On this occasion, I can only of fer a promissory note.

${ }^{57}$ It may well turn out that a judge cannot have the virtue of "judicial wisdom", or phronesis, and lack a sense of justice. Questions about the unity of the judicial virtues will be touche on below.

${ }^{58}$ This judge has no disposition to act justly. Although she may follow the law, she will only do so for reasons other than justice. For example, she might be motivated by considerations of honour and prestige to make decisions that will be seen as legally correct. But as soon as justice and honour part company, she will go for the latter at the expense of the former. 


\section{Is Justice a Virtue?}

There are, however, a number of difficulties with incorporating the virtue of justice into a virtue-centred theory of judging. One such difficulty is that it is not easy to pin down the sense in which "justice" is a virtue at all. Aristotle classified justice as a moral virtue but (famously) found it difficult to fit justice into the schema of virtue as a mean between two opposing vices with respect to a morally neutral affective state, such as an emotion or desire. ${ }^{59}$ If justice is giving persons their due, or doing what is fair, then what are the opposing vices? In the case of an individual, we might be tempted to postulate justice as a mean between the disposition to take more than one's share and the disposition to take less, but this solution has many well-known difficulties, including the problem that taking too little for one's self is not usually characterised as an instance of injustice. In the case of judges, this solution is unavailable in any event. In the usual case, judges do not take for themselves when they do injustice."

If justice does not fit the pattern of temperance, courage, and good temper, then what kind of disposition could justice be? Is justice a disposition or character trait of any kind? Bemard Williams suggests that the notion of a just outcome "is prior to that of a fair or just person. Such a person is one who is disposed to promote just distributions, look for them, stand by them, and so on" (1980, 196-97). "The disposition of justice," Williams continues, "will lead the just person to resist unjust distributions - and to resist them however they are motivated" (1980, 197, emphasis in original). On Williams's account, then, justice is a virtue, but it does not fit the pattern of the other moral virtues. Justice is not a mean with respect to a morally neutral emotion or desire; rather, justice, the virtue, is the disposition to aim at fairness (for a judge, to give the parties that which is due to them). The concept of a fair judicial decision, Williams would argue, exists prior to the virtue of justice.

Williams's picture of the virtue of justice poses an important problem for a virtue-centred theory of judging. If the concept of justice were prior to the virtue of justice, then it would follow that a normative theory of judging cannot be virtue centred. When we ask how judges should decide cases, it would seem that we ought to begin with a theory of what will count as a just outcome. We might then proceed to consider what methods of judging are most likely to lead to such outcomes. The virtues come in as means, but not as ends. The relationship between good judging and the general moral and intellectual virtues would only be contingent, depending on the empirical question as to whether such qualities as courage and temperance are, in fact, conducive to decision in accord with justice. The

59 See Williams 1980

- There are, however, unusual cases. As the discussion of the vice of judicial avarice reminds us, judges sometimes do "take for themselves" when they decide cases. This occurs when a judge takes a bribe or fails to disqualify herself from a case in which she has a financial stake. 
virtue of justice in judging would be derived from one's theory of faimess, and not the other way around.

Of course, it might turn out that just decisions are not wholly independent of the virtues, even if they are prior to them. Thus, it might turn out that only someone with the right character will be good at devising just solutions to difficult problems or discerning the just outcome in a hard case. "But even there," Williams points out, "it is important that, although it took [a virtuous judge], or someone like [a virtuous judge], to think of it, the [decision] can then be recognised as fair independently of that person's character" $(1980,197)$. Moreover, it may tum out that only someone with the virtues will be capable of the disposition to promote just outcomes. That is, nothing in Williams's account precludes the possibility that disposition to do justice is simply not, as a matter of fact, consistent with possession of the vices of avarice, civic cowardice, bad temper, stupidity, and foolishness. ${ }^{61}$ Using the terminology I introduced earlier, Williams can accept a thin theory of judicial virtue and might also accept a thick theory that identified particular virtues as instrumental to just decision making.

Hence, if we accept the centrality of justice for judging and Williams's view that theories of justice are prior to the virtue of justice, it would seem that we could not have a virtue-centred theory of judging. How can virtue jurisprudence answer Williams's challenge? My answer to Williams begins with a second look at the virtue of justice and its structure.

The Structure of Justice

If justice is the disposition to fairness (to give each their due), can we say anything more about this disposition? That is, can we say anything more particular about the question as to what qualities of character make up the virtue of justice, as the disposition to fairness? What constitutes a sense of faimess? What emotional and intellectual equipment disposes and enables a judge to be fair? Is "fairness" really a synonym for "justice," or is the relationship between justice, law, and fairness more complex?

Consider the quality that we might call "judicial impartiality," the disposition to even-handed sympathy or empathy with the parties to a legal dispute. Judges should not identify more strongly with one side than with the other, ${ }^{62}$ but a good judge must be able to understand the interests and passions of all who appear before her. The degree of "partiality" or identification with the viewpoints and interests of the litigants that is appropriate to the role of judge is different from that which is appropriate to other situations. Parents should be partial to their children, and friends partial to

\footnotetext{
61 To avoid confusion, I should note that I do not believe that the paragraph in the text is an answer to the challenge that William's argument poses for a virtue-centred theory of judging.

- "The judicial virtues are those that allow people to stand back from their personal commitments and projects and judge them from an impersonal point of view." Macedo $1990,275$.
} 
one another. Judges should be partial to none, but should possess an appropriate degree of sympathy and empathy with all who appear before them. ${ }^{63}$ A disposition to fairness is constituted in part by having the right sort of emotional equipment for sympathy, an appropriate, even-handed concern for the interests of others.

There is another quality that is closely connected with the disposition to do what is just. The good judge must have a special concern for fidelity to law and for the coherence of law. Let us call this "judicial integrity." ${ }^{64}$ Why is this quality a component of the virtue of justice? Part of the answer lies in a complicated story about the relationship between law and justice. In a common-sense way, we can appreciate that there is a relationship. Assuming we live in a reasonably just society with good laws, then what people are due as a matter of fairness will, in the usual case, correspond to what the law gives them. Characteristically, there are two reasons for this correspondence. On the one hand, good laws meet standards of moral and political fairness. Fidelity to law is clearly a component of a disposition to fairness in such cases. On the other hand, decision according to law is fair because of the values we associate with the ideal of the rule of law. These values, which include legal regularity, publicity, and generality, would be threatened by departure from decision according to law. Even when a judge believes that a particular legal rule might be improved, the just decision will, in the usual case, require fidelity to law; a judge who does otherwise will create uncertainty and inconsistency. Moreover, the absence of such fidelity creates room for other defects (partiality, for example) to have a distorting influence on one's decisions.

Finally, a sense of justice requires the ability to perceive the salient features of particular situations. In the context of judging, we can use Karl Llewellyn's phrase situation sense or, by way of analogy to the phrase moral vision, we can say that a sense of justice requires "legal vision," the ability to size up a case and discern which aspects are legally important. This requires an intellectual grasp of the content of the law, an understanding of the underlying purposes the law serves, and an ability to pick out the features of particular cases that are important for those rules and purposes..$^{65}$ Because the virtue of justice requires legal vision, it is closely tied to the virtue of judicial wisdom.

\footnotetext{
63 I do not mean to imply that judges may never be partial or that persons who do not occupy the judicial role should never be impartial. All of us, judges and non-judges alike, should be partial on the right occasions, towards the right persons, for the right reasons Similarly, we all need the capacity and propensity for impartiality when the situation demands it.

${ }^{64}$ The virtue of judicial integrity expresses in virtue-jurisprudential terms many of the same aims as Dworkin's (1986) theory, "law as integrity."

6 See Sherman 1989.
} 
Justice and the Unity of the Virtues

Thus, we can discern at least three ingredients in the virtue of justice as it applies to judges: judicial impartiality, judicial integrity, and legal vision. Notice, however, that these ingredients do not combine like the various nuts in a party mix. Rather, the ingredients of the virtue of justice combine as do the ingredients of a cake. The whole is not simply the sum of its parts. Hence, sympathetic identification with the interests of litigants makes vivid the rule-of-law values of predictability and certainty that motivate the aspect of judicial integrity I have called fidelity to law. And fidelity to law is not even possible without legal vision, the ability to discern the legally relevant aspects of a particular case in terms of the purposes and values that animate the rules oflaw.

Although the virtue of justice can be analysed into component parts, the value of these components is only fully realised if they all are present together. This point about the unity of justice can be extended to the judicial virtues as a whole. Each judicial virtue requires all of the others, and the virtue of judicial wisdom (phronesis) plays a special unif ying role. This point is expressed by the familiar formula that one can only go right in only one way, but one can go wrong in many ways. The judicial virtues are complete only when they are all present together.

With this point at hand, I can now tum to a preliminary statement of a virtue-centred theory of judging.

D. What Is the Structure of Virtue-Centred Theory of Judging?

For the sake of simplicity and clarity, I shall formulate a virtue-centred theory of judging in the form of five definitions:

- A judicial virtue is a naturally possible disposition of mind or will that when present with the other judicial virtues reliably disposes its possessor to make just decisions. The judicial virtues include but are not limited to temperance, courage, good temper, intelligence, wisdom, and justice.

- A virtuous judge is a judge who possesses the judicial virtues.

- A virtuous decision is a decision made by a virtuous judge acting from the judicial virtues in the circumstances that are relevant to the decision.

- A law ful decision is a decision that would characteristically be made by a virtuous judge in the circumstances that are relevant to the decision."

66 The distinction between virtuous and correct decisions is introduced to distinguish between a fully virtuous decision (made by a virtuous judge acting from the virtues) from a merely correct decision (made for the wrong reasons). In order to be legally correct, a decision need only be the decision a virtuous judge would have made under the circumstances. Thus, a legally correct decision could be made for vicious reasons. For example, a corrupt judge could accept a bribe to render the same decision that a virtuous judge would have made.

- Lawrence B. Solum 2003 
The phrase legally correct is synonymous with the word lawful in this context.

- A just decision is identical to a virtuous decision.

The central normative thesis of a virtue-centred theory of judging is that judges ought to be virtuous and to make virtuous decisions. Judges who lack the virtues should aim to make lawf ul or legally correct decisions, although they may not be able to do this reliably, given that they lack the virtues. Judges who lack the judicial virtues ought to develop them. Judges ought to be selected on the basis of their possession of (or potential for the acquisition of) the judicial virtues.

We can now return to Williams's thesis: the notion of just outcome is prior to and independent of the notion of the virtue of justice. There is a sense in which a just decision may, under certain conditions, be recognised as just without ref erence to the virtues of the judge. In order to clarify this point, we need to sort out a variety of situations in which Williams's thesis holds true. We shall then be able to consider the cases in which Williams's thesis does not ring true.

The first context to consider we might call easy cases. Some decisions will obviously be just. Even persons who have incomplete legal knowledge or who have obtained only an incomplete degree of virtue will be able to recognise the justice of the decision. Even in easy cases, however, someone who is thoroughly blinded by self-interest might not concur in a widely shared judgement about what outcome is just.

There are cases where the justice of a decision is not so obvious as in easy cases. The second context might be called complex cases. When the law is complex, a high degree of legal intelligence may be required to recognise the legally correct result. When the facts are complex, other intellectual skills - for example, a highly developed situation sense may be required to see what even relatively simple legal rules require. Thus, in complex cases, it may be the case that only someone with sufficient legal knowledge and in possession of a high degree of judicial virtue will be able to grasp fully which outcome is just and why this is so. ${ }^{67}$ Although we might say that a just decision is independent of the virtue of the particular judge who made the decision, it is not the case that the justice of the decision is independent of judicial virtue. There are cases in which the just outcome can only be recognised by a virtuous judge.

In both easy cases and complex cases Williams could argue that the criteria for a legally correct decision are antecedent to the virtuous judge. In complex cases, it may take virtue to recognise these criteria, Williams

\footnotetext{
67 In such cases, I am inclined to say that any virtuous person could be brought to see which result is just and why this is so, but the process of bringing about such an understanding may involve quite a lot of explanation.
} 
can concede, but it is the legal rules and the facts that determine the legal correctness of outcomes. In the section that follows, I shall argue that there are cases in which Williams's thesis does not hold.

\section{The Adequacy of a Virtue-Centred Account}

Does virtue jurisprudence offer an adequate theory of judging? I shall answer this question with respect to two kinds of cases, illustrating both the way in which a virtue-centred theory of judging can capture the insights of its rivals and the way in which it might differ from them. The first sort of cases I shall call cases of "justice as lawfulness." These are cases in which the outcome required by the legal rules is in full accord with our sense of fairness. The second sort of cases I shall call cases of "justice as faimess." outcome dictated by the rules of law alone is not consistent with our understanding of what is fair in a wider sense.

\section{A. Justice as Lawfulness}

Can a virtue-centred theory of judging offer an adequate nonnative account of cases, either easy or complex, in which the legal rules determine the lawf ul outcome? The answer is surely yes. For the most part, a virtue-centred theory of judging will be in accord both with common sense and with other nonnative theories of judging with respect to the question as to what constitutes the just outcome in such cases. The virtue of justice ordinarily requires decision in accord with the letter of the law.9 Of course, the reasons offered by various nonnative theories of judging are likely to differ even in easy cases. Utilitarians will emphasise the good consequences that justify the rules and the bad consequences that would result if judges undermined the predictability and certainty created by the laws by failing to adhere to them. Deontologists might emphasise the rights that legal rules protect and the unfairness of failing to follow legal rules once they become a source of legitimate expectations.

The rivals of a virtue-centred theory of judging can agree on the idea that judges ought to possess the judicial virtues in so far as these are required for judges to follow the law reliably. No plausible nonnative theory of judging is inconsistent with a thin theory of the judicial virtues. No sensible theory would be indifferent to judges who are avaricious, cowardly, bad tempered, stupid, or foolish, and no sensible theory would claim we should not prefer temperate, courageous, good-tempered, intelligent, and wise judges. How, then, does a virtue-centred account differ from accounts that do not focus on the virtues?

63 This locution is only coincident with "justice as fairness" in Rawls's (2001) sense.

G See Kraut 2002, 105-08, 117. 
Virtue Is Required to Explain Decisions According to Legal Rules

Unlike other theories of judging, a virtue-centred theory makes the claim that virtue is an ineliminable part of the explanation for and justification of the practice of judging. According to a virtue-centred theory, the whole story about what the rules of law require in particular cases includes the virtues. If they were to be left out, the story would be incomplete. Moreover, a virtue-centred theory suggests that it may require judicial virtue to recognise the legally correct result. The rules do not apply themselves; judgement is always required for a general rule to be applied to a particular case. Practical wisdom or good judgement is required to ensure that the rules are applied correctly.

The necessity for practical wisdom in rule application can be discerned by imagining an appellate judge and her interlocutor discussing the appellate review of a trial judge's finding of fact. "Why was the trial judge's finding of fact clearly erroneous?" the interlocutor asks. "Because it was not sufficiently supported by evidence on the record," answers the judge. "Why do you conclude that the support was insufficient?" asks the interlocutor. "Because a reasonable finder of fact could not move from that evidence to the conclusions that judge drew," answers the judge. "But why couldn't a reasonable finder of fact make the necessary inf erences?" asks the interlocutor. Imagine that the interlocutor responds to each explanation with a demand for definite criteria for application of the clearly erroneous standard. At some point the answers must stop. If the questioner were still unsatisfied, the judge would be forced to explain her lack of further justifications by saying, "Because that's the way I see it, and I am a competent judge. I cannot say any more than that." Explanations must come to an end somewhere. ${ }^{70}$ The clearly erroneous rule provides a particularly perspicuous example of the bottom-line role of practical judgement in rule application, because it is widely acknowledged that no criteria can be provided for sorting errors that are clear from those that are not. ${ }^{71}$

In the end, agreement and disagreement about what rules mean and how they are applied are rooted in practical judgements. Even with respect to some easy cases, and more frequently with respect to complex cases, articulated reasons will not suffice to explain why, in cases of bottom-line disagreement about the application of a rule to the facts, one judgement is legally correct and competing judgements are not.

- See Wittgenstein 1968, $\S 1$

${ }^{71}$ See United States v. Aluminium Company of America $(1945,433)$ (opinion by Learned Hand, J., stating, "It is idle to try to def ine the meaning of the phrase 'clearly erroneous'; all that can be profitably said is that an appellate court, though it will hesitate less to reverse the finding of a judge than that of an administrative tribunal or of a jury, will nevertheless reverse it most reluctantly and only when well persuaded"); see also Cooper 1988. A virtuecentred theory also accounts for the observation that the clearly erroneous rule is applied with an eye to the virtues of the trial-court judge. See James and Hazard $(198), \S 12.8,668)$ "[A]n appellate court's inclination to accept a trial judge's findings depends ... on the court's unstated degree of confidence in the trial judge's fair-mindedness." 
Indeed, a virtue-centred account allows us to appreciate the fact that explanations or justifications of legal decisions play more than one role. In some cases, when a judge explains a decision, the intention is to lay bare the premises and reasoning that moved the judge from accepted premises about the law and the facts to some conclusion about what result is legally correct. There are other cases, however, where explanations play a different role. When the decision of a case is based on legal vision or situation sense - that is, when the decision is based on the virtue of judicial wisdom of phronesis - then the point of an explanation is to enable others to come to see the relevant features of the case. Such explanations do not recreate a decision procedure; rather, they are aimed at enabling others to acquire practical wisdom.

Thus, Bemard Williams's (1980) claim that the notion of a just decision "is prior to that of a fair or just person" is at best partially correct. Even when judges simply apply the rules to the facts, the notion of a just decision cannot be untangled from the notion of a virtuous judge grasping the salient features of the case. Virtue, in particular the virtue of phronesis or judicial wisdom, is a central and ineliminable part of the story.

A Virtue-Centred Account of Lawful Judicial Disagreement

At this point one could object that a virtue-centred account fails for a different reason. It might be argued that a virtue-centred account requires that two inconsistent outcomes in the very same case could both be legally correct. ${ }^{72}$ As we shall see, this apparent objection to a virtue-centred theory of judging actually illuminates one of its greatest strengths. A virtuecentred theory allows us to account for the fact that there are frequently cases in which more than one outcome would count as legally correct.

The objection begins with a premise that we shall call the multiplicity of virtuous decisions. The core idea of this premise is quite simple: there are cases in which different virtuous judges would make different decisions with respect to a given issue and a given set of facts. The second premise we shall call the uniqueness of legally correct decisions. The idea of this premise is that, given a particular issue and a given set of facts, only one decision of the issue can be legally correct. Call the claim that a decision is legally correct if and only if it is the decision that would be made by a virtuous judge under the relevant circumstances the identity of virtue and legality. The shape of the argument should now be clear. From the uniqueness of legally correct decisions and the multiplicity of virtuous decisions it would seem to follow that some virtuous decisions are incorrect. If these premises are true, it follows that the identity of virtue and legality is false.

The first premise, the multiplicity of virtuous decisions, asserts that two

${ }^{72}$ I am grateful to Phillip Pullman for his forceful presentation of this objection and to Linda Zagzebski for her assistance in working out the answer that is presented here.

- Lawrence B. Solum 2003 
different virtuous judges could reach different decisions in the same case. This claim seems plausible. Different virtuous judges are likely to differ in ways that might affect their decisions. They will have different experiences and beliefs, and those differences could easily affect the decision on a variety of legal issues. The multiplicity of virtuous decisions seems especially likely in so-called hard cases, in which there are good legal arguments on both sides of the issue. ${ }^{73}$

However, the second premise, the uniqueness of legally correct decisions, is false. There are a variety of situations in which more than one outcome is legally correct. This is true for a variety of reasons. First, it is sometimes the case that the pre-existing legal rules underdetermine the outcome of a particular case. ${ }^{74}$ In the United States, a frequent pattern involves the situation where an issue of law has been resolved differently by different circuits of the United States Court of Appeal. This phenomenon is called a "circuit split." Unless the Supreme Court resolves the split, inconsistent results can be correct in different circuits. In a circuit that has not decided the issue, two different trial judges can reach different outcomes and neither judge has rendered a decision that is legally incorrect. In this first sort of case, however, one might argue that there is a sense in which the inconsistent decisions are only correct provisionally or temporarily. If the Supreme Court resolves the split, then one line of cases is approved and the inconsistent line becomes "bad law."

Of course, there are times when a circuit split is best explained as a competition between a correct line of authority and another position that is badly reasoned or that ignores relevant authority. But there are other times when both results are plausible. Because the Supreme Court leaves many circuit splits unresolved (for years, decades, or even permanently), the best description of the situation is that two inconsistent positions on the same issue of law are both correct; neither line of authority can be said to be bad law.

Second, it is sometimes the case that the law itself commits a decision to the discretion of the judge. A paradigm case of such discretion can be found in the power of trial judges to manage the mechanics of a trial. Trialcourt judges have discretion to decide how long a trial will last, how many

\footnotetext{
${ }^{73}$ Although I concede the multiplicity of virtuous decisions, I should note that this premise might be attacked in a variety of ways. For example, we might argue that although different partially virtuous judges might decide the same issue in the same case differently, only one decision could and would be made by the fully virtuous judge. Put another way, we might say that the various decisions made by different judges who possess the virtuous to different degrees converge on a single decision as the degree of virtue increases. This picture may fit some kinds of issues and cases, but I shall demonstrate that there are issues and cases that do not fit into the picture of increasing virtue converging on a unique outcome.

${ }^{74}$ See Solum 1987 (distinguishing indeterminate from underdeterminate). This assertion is, of course, controversial. I have not here addressed the important and persuasive arguments made by Ronald Dworkin (1985).
} 
witnesses each side can present, and how long the examination of a witness will be pennitted to take. If a virtuous judge makes such a decision, then it is legally correct, even though another virtuous judge would have made a different decision. If, however, the decision was the product of judicial vice - for example, it was a product of corruption - then the decision is in error - even though the very same decision would have been legally correct if it had been the product of virtue rather than vice. The law of procedure captures this phenomenon in the standard of appellate review for discretionary decisions. The relevant standard is called "abuse of discretion," and given an abuse-of-discretion standard it is settled law that inconsistent decisions of the same issue on identical legally relevant facts can both be legally correct. ${ }^{75}$

Moreover, some legal standards sanction more than one legally correct outcome on a particular set of facts. A clear example of this is the "best interests of the child" standard in child-custody disputes. Although formulated as a rule of law, this legal standard requires the application of practical judgement to a particular fact situation. As a consequence, an appellate court will affirm a trial court's decision to award custody, even when the appellate judges would have made a different decision. ${ }^{76}$ In such a case, each of two inconsistent decisions (awarding primary custody to one parent versus the other) can be legally correct. Although "best" is superlative and therefore suggests a unique outcome, the best-interests-of-thechild standard is understood by courts to permit a multiplicity of outcomes in the large range of cases in which both parents have good claims that they would provide the best for the child.

A virtue-centred theory of judging explains and justifies this feature of our judicial practice. There are circumstances in which two or more different (and in one sense "inconsistent") outcomes are legally correct. A virtue-centred theory explains this on the grounds that two different virtuous judges could each make different decisions, even though each was acting from the virtues. In cases in which the judge was not acting from virtue but was acting from vicious motives, such as corruption, wilful disregard of the law, or bias, then a discretionary decision may be legally incorrect - even though the very same outcome would have been acceptable if it had been made by a virtuous judge.

\section{B. The Virtue of Equity}

The distinctive contribution of a virtue-centred theory is even clearer in the second category of cases, those in which the result required by the legal

\footnotetext{
75 See, e.g., Jones v. Strayhorn 1959: "The mere fact or circumstance that a trial judge may decide a matter within his discretionary authority in a manner different from what an appellate judge would decide if placed in a similar circumstance does not demonstrate that an abuse of discretion has occurred."

${ }^{76}$ See Ford v. Ford 2002 (indicating that a difference of judgement does not justify reversal of a child-custody decision absent "abuse of discretion").
} 
rule is inconsistent with our notion of what is fair. In these cases, a virtuecentred theory suggests that the virtuous decision is guided by the virtue of equity, or justice as fairness, distinguished from justice as lawf ulness. ${ }^{77}$

The notion of equity as departure from the rules is rooted in Aristotle, and the best place to begin an exposition is with Aristotle's statement of the problem of equity and justice:

What causes the difficulty is the fact that equity is just, but not what is legally just: it is a rectifican of legal justice. The explanation of this is that all law is universal, and there are some things about which it is not possible to pronounce rightly in general terms; therefore in cases where it is necessary to make a general pronouncement, but impossible to do so rightly, the law takes account of the majority of cases, though not unaware that in this way errors are made. And the law is nonetheless right; because the error lies not in the law nor in the legislator but in the nature of the case; for the raw material of human behaviour is essentially of this kind. (Aristotle 1976, 1137b9-1 137b24)

This is the core of Aristotle's view of epieikeia, usually translated as "equity" or "fair-mindedness." As is frequently the case with Aristotle, the text is ambiguous. Aristotle and his contemporary expositors ${ }^{78}$ inform my account of equity, but I do not claim that my interpretation is Aristotle's own view.

One characteristic of equity is that it involves a departure from the rules. Any general rule may be overinclusive or underinclusive with respect to the goal the rule is meant to achieve. ${ }^{79}$ Equity corrects the law's generality by making exceptions in cases in which the rule leads to unanticipated and unjust results. An equitable departure from the rules can relate to the intentions of legislators in two distinct ways. In some cases, doing equity requires the judge to realise the intention of the legislature. In other cases, it may require the judge to correct a defect in the law that the legislator did not or could not have anticipated - for example, in cases in which circumstances have changed or previously unknown facts have come to light.

A second characteristic of equity is its particularism. Equity tailors the law to the requirements of the particular case. Understanding equity as a particularised practice allows us to distinguish it from other practices that involve a departure from legal rules. For example, equity is not identical to the resolution of conflicts between law and morality in favour of the latter. Judges might nullify a statute that legalised the practice of human slavery on the grounds that slavery is always morally wrong. This is not an example of the practice of equity, because such a decision would not involve a departure from the rule on the basis of the facts of the particular

77 See Shiner 1994.

72 See Shiner 1994; Kraut 2002, 108-11

79 See Schauer 1991. 
case. Rather, the decision would be based on a general moral principle for example, that wicked or immoral statutes should not be enforced.

Equity is the tailoring of the law to the demands of the particular situation. For this reason, equity can (or should) be done only by a phronimos, a judge with moral and legal vision. Only a virtuous judge can do equity. Putting the point a bit differently, we could say that "equity," the practice, should only be done by judges who possess "equity," the virtue. As Roger Shiner (1994, 1260-61) puts it: "Equity is the virtue shown by one particular kind of agent - a judge - when making practical judgements in the face of the limitations of one particular kind of practical rule - those hardened customs and written laws that constitute for some societies the institutionalised system of nonns that is its legal system."

A virtue-centred theory of judging offers a distinctive approach to cases that involve considerations of equity. Here is one way to put it. Other normative theories of judging have difficulty explaining why there should be a distinctive practice of equity. If an exception ought to be made to a legal rule, then amend the rule. (This is the approach favoured by theories of statutory interpretation that require strict adherence to plain meaning.) Of course, sometimes rules should be amended, but a virtue-centred theory of judging stakes out the claim that there will be always be cases in which the problem is not that the rule was not given its optimal formulation. Rather, the problem is that the infinite variety and complexity of particular fact situations outruns our capacity to formulate general rules. The solution is not to attempt to write the ultimate code, with particular provisions to handle every possible factual variation. No matter how long and detailed, no matter how many exceptions, and exceptions to exceptions, the code could not be long enough. ${ }^{30}$ Rather, the solution is to entrust decision to virtuous judges who can craft a decision to fit the particular case. No thin theory of judicial virtue can incorporate the virtue of equity. Indeed, I shall stake the claim that only a virtue-centred theory offers a fully adequate explanation of equity. ${ }^{81}$ But Aristotle is right about rules; no set of rules can do justice in every case. Thus, I believe that the argument of this essay provides grounds for the following claim: Virtue jurisprudence offers a normative and explanatory theory of judging that explains and justifies the practice of equity, but many other theories of law stumble at precisely this point.

81 Even if the code could be long enough, it would not be a good idea to make it "complete," when by "complete" we mean the code is sufficiently particularistic as to provide, in theory, a guide to decision making in every possible case. The complete code would be so long and so complex that it would be of no practical use as a guide to decision. Cf. Solum 1993, 324-27 (arguing for analogous thesis in context of notion of a complete contract).

21 Of course, a defence of this claim requires an examination of all the alternative normative theories of judging. Because this task goes beyond the scope of this essay, I can only offer a promissory note on this occasion. 


\section{Conclusion}

This essay has examined one component of virtue jurisprudence, a virtuecentred theory of judging. Its aim has been to clarify the sense in which a theory of judging may be said to be virtue centred and to argue that a virtue-centred theory is plausible. The advantages of a virtue-centred account have been illustrated in two contexts. Where justice requires a decision that accords with the legal rules, a virtue-centred theory accords with common sense but explains both the role of practical judgement in rule application and the phenomenon of legal disagreement. Where justice requires a departure from the rules, a virtue-centred theory explains and justifies the practice of equity. Virtue jurisprudence does the work we hope a theory of judging can do.

Loyola Law School

919 S. Albany St.

Los Angeles, CA 90015

USA

Lawrence.Solum@lls.edu

\section{Acknowledgments}

I am grateful to Sharon Iloyd and Roger Shiner for their comments on "Should Judges Be Virtuous?" an earlier and substantially different version of this essay, presented at the Pacific Division of the American Philosophical Association on 27 March 1998. I also owe thanks to the participants in the Southern Califonia Law and Philosophy Discussion Group for comments on a draft presented on 13 February 2002. I am especially grateful to Antony Duff for the comments he presented at the Stirling Conference on 3 March 2002. On that occasion, I received valuable comments too from Linda Zagzebski and Phillip Pullman. I have also benefited from numerous comments on my previous work on virtue jurisprudence: in this regard, I owe special thanks to Steven Burton, Kent Greenawalt, Stephen Macedo, Richard Posner, Frederick Schauer, and Ian Shapiro.

\section{References}

Aaronson, Mark Neal. 1995. "Be Just to One Another: Preliminary Thoughts on Civility, Moral Character, and Professionalism." St. Thomas Law Review 8: 113ff.

- - - . 1998. "We Ask You To Consider: Learning About Practical Judgement In Lawyering." Clinical Law Review 4: $247 f$ f.

Anscombe, Elizabeth. 1997. "Modern Moral Philosophy." In Virtue Ethics: Oxford Readings in Philosophy, edited by Roger Crisp and Michael Slote, 26-44. Oxford: Oxford University Press. 
Araujo, Robert J. 1994. "Moral Issues and the Virtuous Judge: Reflections on the Nomination and Confirmation of Supreme Court Justices." Catholic Lawyers 35: $311 \mathrm{ff}$.

- - . 1997. "The Virtuous Lawyer: Paradigm and Possibility." SMU Law Review 50: 433ff.

- - . 2002. "Justice as Right Relationship: A Philosophical and Theological Reflection on Affirmative Action." Pepp. Law Review 27: $377 f$.

Aristotle. 1976. The Ethics of Aristotle: The Nicomachean Ethics, translated by J. A. K. Thomson, revised by Hugh Tredennick. London: Penguin.

Bainbridge, Stephen M. 1997. "Community and Statism: A Conservative Contractarian Critique of Progressive Corporate Law Scholarship." Cornell Law Review 82: 856ff.

Baker, C. Edwin. 1985. "Sandel on Rawls." U. Pa. Law Review 133: 895ff.

Baldwin, Dick. 1997. "Lawyers, Justice \& Money." Oregon State Business Bulletin (October): 58ff.

Bamett, Randy. 1998. The Structure of Liberty. Oxford: Oxford University Press.

Beck-Dudley, Caryn L. 1996. "No More Quandries: A Look at Virtue Through the Eyes of Robert Solomon." American Business Law Journal 34: 117.

Bentham, Jeremy. 1988. A Fragment on Government, edited by J. H. Bums, Ross Harrison, and Herbert L. Hart. Cambridge: Cambridge University Press.

- - - 1996. An Introduction to the Principles of Morals and Legislation, edited by J. H. Bums, Herbert L. Hart, and J. Rosen, Cambridge: Cambridge University Press.

Bricker, David C. 1999. "A Kantian Argument for Native American Cultural Survival." U. Det. Mercy Law Review 76: 789ff.

Broadie, Sarah. 1991. Ethics with Aristotle, Oxford: Oxford University Press.

Brosnan, Donald F. 1989. "Virtue Ethics in a Perfectionist Theory of Law and Justice." Cardozo Law Review 11: 335ff.

Byrne, Donna M. 1995. "Progressive Taxation Revisited." Arizona Law Review 37: 739ff.

Carens, Joseph H. 1987. "Aliens and Citizens: The Case for Open Borders." Review of Policy 49: 251ff.

Cochran, Robert F. 1996. "Lawyers and Virtues." Notre Dame Law Review 71: 707.

- - . 1998. "Crime, Conf ession, and the Counselor-At-Law: Lessons From Dostoyevsky." Hous. Law Review 35: 327ff.

- - . 2000. "Professionalism in the Postmodern Age: Its Death, Attempts at Resuscitation, and Altemate Sources of Virtue." Notre Dame Journal of Law Ethics and Public Policy 214: 305.

- Lawrence B. Solum 2003 
Cooper, Edward H. 1988. "Civil Rule 50(A): Rationing and Rationalizing the Resources of Appellate Review." Notre Dame Law Review 63: $645 f f$.

Crisp, Roger, editor. 1996. How Should One Live?: Essays on the Virtues. Oxford: Clarendon Press.

Crisp, Roger, and Michael Slote, editors. 1997. Virtue Ethics: Oxford Readings in Philosophy. Oxford: Oxford University Press.

Dickson, Julie. 2001. Evaluation and Legal Theory. Oxford: Hart Publishing.

Dworkin, Ronald. 1978. "Hard Cases." In Taking Rights Seriously, 81ff. London: Duckworth.

- - - 1985. "Is There Really No Right Answer in Hard Cases?" In A Matter of Principle, 119-44. Cambridge, Mass.: Harvard University Press.

- - - 1986. Law's Empire. Oxford: Hart Publishing.

EngbergPedersen, Troels. 1983. Aristotle's Theory of Moral Insight. Louisville, Ky.: Westminster John Knox Press.

Fairweather, Abrol, and Linda Zagzebski, editors. 2001. Virtue Epistemology: Essays on Epistemic Virtue and Responsibility, Oxford: Oxford University Press.

Farber, Daniel A. 1991. "The Inevitability of Practical Reason: Statutes, Formalism, and the Rule of Law." Vanderbilt Law Review 45: 533ff.

Feldman, Heidi Li. 1996. "Codes and Virtues: Can Good Lawyers Be Good Ethical Deliberators?" Southern California Law Review 69: $885 f$ f.

- - . 1999. "Beyond the Model Rules: The Place of Examples in Legal Ethics." Geo. Journal of Legal Ethics 12: 409ff.

- - . 2000. "Prudence, Benevolence, and Negligence: Virtue Ethics and Tort Law." Chi.-Kent Law Review 74: $1431 \mathrm{ff}$.

Fleming, James E. 2000. "The Parsimony of Libertarianism." Constitutional Commentary 17: $171 \mathrm{ff}$.

Foot, Philippa. 1978. Virtues and Vices. Oxford: Clarendon Press.

- - - Natural Goodness. Oxford: Clarendon Press.

Forbath, William E. 2001. "Constitutional Welfare Rights: A History, Critique, and Reconstruction." Fordham Law Review 69: 1821ff.

Ford v. Ford. 2002. 68 Conn. App. 173, 187, 789.

Gaba, Jeffrey. 1999a. "Environmental Ethics and Our Moral Relationship to Future Generations: Future Rights and Present Value." Columbia Journal of Environmental Law 24: $249 \mathrm{ff}$.

- - . 1999b. "Environmental Ethics and Our Moral Relationship to Future Generations: Future Rights and Present Virtue." Columbia Journal Environmental Law 24: 249ff.

Galston, Miriam. 1994. "Taking Aristotle Seriously: Republican-Oriented Legal Theory and the Moral Foundation of Deliberative Democracy." California Law Review 82: 329ff. 
Garcia, Frank J. 2000. "Trade and Inequality: Economic Justice and the Developing World." Michigan Journal of International Law 21: $975 \mathrm{ff}$.

Garcia, J. L. A. 2001. "Topics in the New Natural Law Theory." American Journal of Juris prudence 46: 51ff.

Gentiles v. State Bar of Nevada. 1991. 111 S. Ct. 2720.

George, Robert P. 1995. Making Men Moral: Civil Liberties and Public Morality. Oxf ord: Clarendon Press.

Glendon, Mary Ann. 1994. A Nation Under Lawyers: How the Crisis in the Legal Profession is Transforming Americ an Society. Cambridge, Mass: Harvard University Press.

Gordon, Wendy J. 1989. "An Inquiry into the Merits of Copyright: The Challenges of Consistency, Consent, and Encouragement Theory." Stanford Law Review 41: 1343ff.

Haemmerli, Alice, 1999. "Whose Who? The Case for a Kantian Right of Publicity." Duke Law Journal 49: 383ff.

Hardie, W. F. R. 1980. Aristotle's Ethical Theory. Oxford: Oxford University Press.

Harsch, Bradley A. 1999. "Consumerism and Environmental Policy: Moving Past Consumer Culture." Ecology Law Quarterly 26: 543ff.

Henry, Rebecca S. 1999. "The Virtue in Discretion: Ethics, Justice, and Why Judges Must Be 'Students of the Soul." New York University Review of Law \& Social Change 25: 65ff.

Heyman, Steven J. 1992. "Aristotle on Political Justice." Iowa Law Review 77: 851ff.

Herman, Barbara. 1988. "Comment on Gavison." Southern California Law Review 61: 1663ff.

Hirschman, Linda R. 1990. "The Virtue of Liberality in American Communal Iife." Michigan Law Review 88: 983ff.

- - - 1992. "The Book of 'A."' Texas Law Review 70: 971ff.

- - - 1993. "Nobody in Here but Us Chickens: Legal Education and the Virtues of the Ruler." Stanford Law Review 45: 1905ff.

Housman, Robert F. 1992. "Kantian Approach to Trade and the Environment." 49 Washington and Lee Law Review 49: 1373ff.

Horvitz, Ellis J. 1997. "Otto Kaus Remembered." Loyola Los Angeles Law Review 30: $961 \mathrm{ff}$.

Hudson, Walter M. 1999. "Book Review, Obeying Orders: Atrocity, Military Discipline, and the Law of War." Military Law Review 161: $225 \mathrm{ff}$.

Huigens, Kyron. 1995. "Virtue and Inculpation." Harvard Law Review 108: $1423 f f$.

- - . 1998. "Virtue and Criminal Negligence." Buffalo Criminal Law Review 1: 431ff.

- - . 2000a. "The Dead End of Deterrence, and Beyond." Wm. and Mary Law Review 41: $943 f$ f.

- - . 2000b. "Rethinking the Penalty Phase." Arizona State Law Journal 32: 1195ff.

- Lawrence B. Solum 2003 
- - . 2002. "Solving the Apprendi Puzzle." Geo. Law Journal 90: $387 f$.

Hursthouse, Rosalind. 1999. On Virtue Ethics, Oxford: Oxford University Press.

Jackson, Thomas H. 1986. The Logic and Limits of Bankruptcy Law. Cambridge, Mass.: Beard Books.

James, Fleming, and Geoffrey Hazard. 1985. Civil Procedure. Boston: Little, Brown.

Jones v. Strayhorn. 1959. 159 Tex. 421, 321 S.W.

Kaplow, Louis, and Stephen Shavell. 2002. Fairness Versus Welfare. Cambridge, Mass: Harvard University Press.

Kleinwort Benson Ltd. Appellant v. Lincoln City Council Same Respondent. 1999. 2 A.C. 349.

Kraut, Richard. 1989. Aristotle on the Human Good. Princeton: Princeton University Press.

- - - 2002. Aristotle: Political Philosophy. Oxford: Clarendon Press.

Kromnan, Anthony T. 1993. The Lost Lawyer: Failing Ideals of the Legal Profession. Cambridge, Mass: Harvard University Press.

Lillich, Richard B. 1997. "Kant and the Current Debate Over Humanitarian Intervention." Journal Transnational Law and Policy 6: 397.

Llewellyn, Karl. 1960. The Common-Law Tradition. Boston: Little, Brown.

Luban, David. 1992. "Justice Holmes and Judicial Virtue." Nomos 34: $235 f$ f.

Macedo, Stephen. 1990. Liberal Virtues. Oxford: Clarendon Press.

MacIntyre, Alasdair. 1984. After Virtue: A Study in Moral Theory. London: Duckworth.

Maitland, F. W. 1898. "A Prologue to a History of English Law." Law Quarterly Review 14: 13ff.

Modak-Truran, Mark C. 2000. "Corrective Justice and the Revival of Judicial Virtue." Yale Journal of Law and Humanities 12: 249ff.

Muller, Eric L. 1993. "The Virtue of Mercy in Criminal Sentencing." Seton Hall Law Review 24: $288 f$ f.

National Commission on Judicial Discipline and Removal. 1993. Report. Washington, D.C.: Govermnent Printing Office.

Nesteruk, Jeffrey. 1996a. "Law, Virtue, and the Corporation." American Business Law Journal 33: 473ff.

- - . 1996b. "The Moral Dynamics of Law in Business." American Business Law Journal 34: 133ff.

Nozick, Robert. 1977. Anarchy, State, and Utopia. Oxford: Basil Blackwell.

Osiel, Mark J. 1998. "Obeying Orders: Atrocity, Military Discipline, and the Law of War." California Law Review 86: 939ff.

Pears, David. 1980. "Courage as a Mean." In Essays on Aristotle's Ethics, edited by A. O. Rorty, 171ff. Berkeley: University of California Press. 
Perkins, James W. 1998. "Virtues and the Lawyer." Catholic Lawyers 38: $185 f f$.

Pinkard, Terry. 1992. "Judicial Virtue and Democratic Politics." Nomos 34: 265.

Quinn, Kevin P. 2000. "Viewing Health Care as a Common Good: Looking Beyond Political Liberalism." Southern California Law Review 73: 277ff.

Rawls, John. 1951. "Outline of a Decision Procedure for Ethics." Philosophical Review 60: 177ff.

- - . 1999. A Theory of Justice. Cambridge, Mass.: Harvard University Press.

- - - 2001. Justice as Fairness: A Restatement. Cambridge, Mass.: Harvard University Press.

Resnick, Judith. 1982. "Managerial Judges." Harvard Law Review 96: $374 f$.

Robertson, Elbert L. 2000. "A Corrective Justice Theory of Antitrust Regulation." Catholic U. Law Review 49: 741ff.

Rorty, A. O., editor. 1980. Essays on Aristotle's Ethics. Berkeley: University of California Press.

Sandel, Michael J. 1988. Liberalism and the Limits of Justice, Cambridge: Cambridge University Press.

Shaffer, Thomas L. 1993. "The Legal Profession's Rule Against Vouching for Clients: Advocacy and "The Manner That Is The Man Himself." Notre Dame Journal of Law, Ethics and Public Policy 7: 145ff.

Shiner, Roger. 1994. "Aristotle's Theory of Equity." Loyola Los Angeles Law Review 27: 1245.

Scharffs, Brett G. 2001. "Law as Craft." Vanderbilt Law Review 54: $2245 f$.

Schauer, Frederick. 1991. Playing by the Rules: A Philosophical Examination of Rule-Based Decision-Making in Law and Life. Oxford: Clarendon Press.

- - - 1996. "Positivism as Pariah." In The Autonomy of Law: Essays on Legal Positivism, edited by Robert P. George. Oxford: Clarendon Press.

Schroeder, Christopher H. 1986. "Rights Against Risks." Columbia Law Review 86: 495ff.

Shennan, Nancy. 1989. The Fabric of Character. Oxford: Clarendon Press.

Simon, Maria. 1994. "Note, Bribery and Other Not So "Good Behaviour "': Criminal Prosecution as a Supplement to Impeachment of Federal Judges." Columbia Law Review 94: 1617ff.

Simons, Kenneth W. 2001. "The Hand Formula in the Draft Restatement (Third) of Torts: Encompassing Fairness as Well as Efficiency Values." Vanderbilt Law Review 54: $901 \mathrm{ff}$.

Smith, Abbe, and William Montross. 1999. "The Calling of Criminal Defence." Mercer Law Review 50: 443ff., esp. 511-33. 
Solum, Lawrence B. 1987. "On the Indeterminacy Crisis: Critiquing Critical Dogma." U. Chi. Law Review 54: 462ff.

- - - 1988. "The Virtues and Vices of a Judge: An Aristotelian Guide to Judicial Selection." Southern California Law Review 1730.

- - - 1990. "Virtues and Voices." Chi-Kent Law Review 66: $111 \mathrm{ff}$.

- - . 1991. "What Remains of Freedom of Speech for Lawyers after Gentile?" California Litigation (November): 16ff.

$-\ldots$. 1993. "The Boundaries of Legal Discourse and the Debate over Default Rules in Contract." Southern California Multidisciplinary Law Review 3: 311ff.

- - . 1994a. "Equity and the Rule of Law." Nomos 34: 120.

- - . 1994b. "Situating Political Liberalism." Chi-Kent Law Review 69: 549ff.

- - . 1999. "The Foundations of Liberty." Michigan Law Review 97: $1781 \mathrm{ff}$.

Statman, Daniel, editor. 1997. Virtue Ethics: A Critical Reader. Edinburgh: Edinburgh University Press.

Strudler, Alan, and Eric W. Orts. 1999. "Moral Principle in the Law of Insider Trading." Texas Law Review 78: 375ff.

Sulentic, Alison M. 2001. "Happiness and ERISA: Reflections on the Lessons of Aristotle's Nicomachean Ethics for Sponsors of Employee Benef it Plans." Employee Rights and Employment Policy Journal 5: 7ff. Symposium on Kantian Legal Theory. 1987. Columbia Law Review 87: $421 \mathrm{ff}$.

Transworld Airlines v. American Coupon Exchange. 1990. 913 F.2d 676.

Tremblay, Paul R. 1999a. "Acting 'A Very Moral Type of God': Triage Among Poor Clients." Fordham Law Review 67: 2475ff.

- - . 1999b. "The New Casuistry." Geo. Journal of Legal Ethics 12: $489 f f$.

Twining, William. 1973. Karl Llewellyn and the Realist Movement. Norman: University of Oklahoma Press.

United States v. Aluminium Company of America. 1945. 148 F.2d 416.

Waldron, Jeremy. 1999. The Dignity of Legislation, 189ff. Cambridge: Cambridge University Press.

Williams, Bemard. 1980. "Justice as a Virtue." In Essays on Aristotle's Ethics, edited by A. O. Rorty. Berkeley: University of California Press.

Wittgenstein, Ludwig. 1968. Philosophical Investigations, translated by G. E. M. Anscombe. Oxford: Basil Blackwell.

Wright, R. George. 2002. "Treating Persons as Ends in Themselves: The Legal Implications of a Kantian Principle." U. Rich. Law Review 36: $271 \mathrm{ff}$.

Younger v. Smith. 1973. 30 Cal. App. 3d 138, 106 Cal. Rptr. 225.

Zagzebski, Linda. 1996. Virtues of the Mind: An Inquiry into the Nature of Virtue and the Ethical Foundations of Knowledge. Cambridge: Cambridge University Press. 